\title{
Texts and Textuality
}

\section{Claudia Mitchell and Jacqueline Reid-Walsh}

\section{$\cos 80$}

The fifty-fifth session of the Commission on the Status of Women took place at the United Nations Headquarters in New York from 22 February to 04 March 2011. Representatives from Member States, UN entities and Economic and Social Council (ECOSOC)-accredited NGOS from all regions of the world attended the session. Amongst the many themes and issues discussed, several were critical: as a priority area, the access of girls and women to education, training and science; as a review theme, the elimination of all forms of discrimination and violence against girls; and as an emerging theme, sustainable development and gender equality. These themes and issues highlight the significance of literacies, literatures and technologies (old and new) in the lives of girls, but they also signal the presence (and absence) of other texts such as policies and policy documents in relation to such areas as, for example, Teachers' Codes of Conduct, and Water and Sanitation that affect the lives of girls around the world.

Clearly, texts and textuality, the theme of this issue of Girlhood Studies, need to be at the center of scholarship related to the lives of girls and young women. Is there a text in this class? is the title of the now famous collection of essays by literary critic, Stanley Fish. While Fish's provocative title, offered more than thirty years ago in 1980, applied primarily to literary texts, his contribution to considering the interpretive possibilities within the reader and the text are significant. Similarly, Louise Rosenblatt's The reader, the text and the poem, published just two years earlier, draws attention to the complicated relationships between and amongst readers, texts and important aspects of meaningmaking. Although neither Fish nor Rosenblatt referred specifically to young readers, in some ways their interest in the readers of texts as actively producing meaning anticipates the current fascination with DIY culture.

In this issue of Girlhood Studies, our guest co-editor, Kristin Bratt, and Jacqueline Reid-Walsh bring together a collection of essays that represent something of the breadth and depth of literary and media 
texts within girlhood culture. Some of the essays focus primarily on the nature and content of texts that are being written (mostly by adults) for the girl-market - what John Fiske (1987) would refer to as the primary texts. Other essays take up and examine the ways in which girls as audience (Fiske's audience texts) insert themselves into their reading or viewing. Significantly, however, as one of the images in the visual essay "Girls Use Digital Photography to Speak Out about Sexuality and HIV" so dramatically highlights, we need to think about girls as producers (Fiske's producer texts) and the ways in which they can be at the centre of cultural production: "It's [their] time to be heard."

\section{References}

Fish, Stanley Eugene. 1980. Is There a Text in This Class? The Authority of Interpretive Communities. Cambridge, MA: Harvard University Press.

Fiske, John. 1987. "British Cultural Studies and Television." Pp. 284-326 in Channels of discourse: television and contemporary criticism, ed. Robert Allen. London: Methuen.

Rosenblatt, Louise. 1978. The Reader, the Text, and the Poem: The Transactional Theory of the Literary Text. Carbondale and Edwardsville, IL: Southern Illinois University Press. 